\title{
INFLUENCE OF LEGUMES ON MICROBIAL ACTIVITY IN SOIL
}

\author{
By \\ Armi KaILA \\ Institute of Agricultural Chemistry, University of Helsinki.
}

Received 8th September 1951.

The influence higher plants are known to exert upon the development of soil microflora is of the highest importance. The abundance and quality of the microscopic population in the soil has been found to depend more on the crop than on the moisture, temperature and acidity of their environment, provided these factors vary within natural ranges (5). Even the so called seasonal fluctuation of microorganisms in the soil is attributed to the development of the higher plants (14). Plants modify the soil structure by the penetration of their roots, thus causing changes in the aeration and moisture conditions of the soil. They withdraw mineral nutrients from soil, and excrete carbon dioxide and various organic compounds, and after their death large amounts of organic matter remains in the soil. All this affects the development of soil microorganisms, and since both the activities of various plants and the amount and quality of their residues vary, the population harbouring the soil under and after each crop has its own characteristics.

There is some evidence that the rhizosphere of the legumes affords especially favourable conditions for the development of an abundant and active microflora. In order to elucidate the influence of legumes upon the microbial population and its activity in the soil, some experiments were conducted in connection with some other investigations. The annual legumes, field pea and vetch, were compared with oats, both as single and mixed crops. Red clover represented ley legumes, and its influence upon the soil microflora was investigated in comparison with that of timothy.

\section{Materials and methods.}

Material for this investigation was collected from the field experiments of the Agricultural Research Centre in the neighbourhood of Helsinki, during the summers 1949 and 1950. The main part of the material was taken in the latter year. The experiments sampled were the following: 
Experiment S I: Contained plots of oats, of mixed oats and pea (ratio in the seed $50: 50$ ), of pea, of mixed oats and vetch (ratio in the seed $50: 50$ ), and of vetch.

Experiment S II: Residual effect of crops similar to those in experiment S I; crop: barley.

Experiment N I: Contained plots of timothy, of timothy and red clover (ratio in the seed $10: 15)$, and of red clover. Plants were sown the previous spring.

Experiment N II: Residual effect of ley plants, similar to those in experiment N I; crop: summer wheat.

The soil in all these experiments was finesand clay. In all the experiments the plots received normal amounts of phosphorus and potassium fertilizers as spring dressings. Nitrogen was applied only to timothy plots of experiment N I at the beginning of May.

Soil samples for the various investigations were taken with a bore, six or eight borings from each plot. The samples were taken down to the depth of the ploughing layer. Samples from the four or five replicate plots were combined and thoroughly mixed. Fresh samples were used for the experiments.

The rhizosphere samples were taken using the technique of WALLACE and LOCHHEAD (18): The root systems of ten plants of every kind were collected, shaken as free as possible of soil and placed in $100 \mathrm{ml}$ of sterile tap water. After thorough mixing, inoculations were made. The abundance of bacteria in the rhizospheres was estimated by common plate count using yeastwater-soilextract agar, mineral agar containing aspartic acid or ammonium sulfate as a source of nitrogen, and nitrogen-free mannitol agar. Eight replicates of each were made, and the Petri dishes were incubated for 5 days at $26^{\circ} \mathrm{C}$. The tests for nitrogen fixation were performed using nitrogen-free mannitol solution inoculated with the root suspensions. The nitrogen was determined by the common Kjeldahl procedure.

The increase in the nitrate-nitrogen content of soil samples after an incubation period of four weeks was taken to indicate the intensity of nitrification. The nitratenitrogen was determined by the somewhat modified method of BERGE (1).

The rate of soil respiration was estimated by collecting in sodium hydroxide solution the carbon dioxide evolved from soil incubated in big desiccators.

At the moment there is no simple method for testing the significance of the differences between such figures as those obtained in this investigation through subtraction to represent the amounts of nitrified nitrogen or of nitrogen fixed. In absence of anything better, the supposition was made that these values represent means for samples drawn from populations with the same variance, and the probability tables for normal distribution were applied (cf. 12, p. 80). Since it seemed justifiable to assume that the variation in the results of the replicate estimations arises from analytical errors, the standard deviation for the means of the replicate observations was calculated from the material of the whole experiment (cf. 3, pp. 209-211). 
Observations about the leguminous and non-leguminous rhizosphere microflora.

Several authors report larger numbers of bacteria in the rhizospheres of legumes as compared with those of non-legumes $(4,6,9,16)$. The species most frequently stated as being favoured by legume roots are members of the Radiobacter group $(9,15)$. In recent investigations Canadian microbiologists noted differences in the nutritional quality of the rhizosphere flora of legumes and non-legumes (18, 19). They found that legumes, particularly, appear to exert a pronounced effect in stimulating significantly the bacteria of those groups which require only mineral nutrients, or simple amino acids, or amino acids and growth factors. The authors consider this to be of interest in connection with the demonstration of amino acids excretion by the leguminous plants.

Within the bounds of this investigation some simple tests were made to ascertain the abundance and quality of the rhizosphere population of annual legumes and non-legumes. In summer 1949, plate counts of bacteria growing on various agar media were made from the rhizosphere of oat, pea, and vetch plants at three different stages of growth.

The results, reported in Table 1 , are calculated as millions per ten plants, as this is supposed to give a more accurate picture of the density of the microbes than figures on the number of organisms per gram of root dry matter, or per gram of adhering soil. The data can be taken to give the magnitude class of the microbes approximately only. No colonies appeared on the nitrogen free mannitol agar.

At the beginning of the growing season the pea plants appear to support a more abundant bacterial flora than the vetch or the oat plants. Later in the summer, oat roots reach the microbial density of pea roots, but at the end of the growing season pea plants show their superiority again. The rhizosphere flora of vetch growing on these media, remains poor through the whole season.

Table 1. Abundance of bacteria in the rhizosphere of oat, pea, and vetch plants

(Expressed as millions per ten plants).

\begin{tabular}{|c|c|c|c|c|c|c|}
\hline \multirow{3}{*}{$\begin{array}{c}\text { Date of } \\
\text { samplings }\end{array}$} & \multirow{3}{*}{ Plant } & \multicolumn{2}{|c|}{ Weight of } & \multicolumn{3}{|c|}{ Bacteria developing upon } \\
\hline & & roots & adhering soil & $\begin{array}{l}\text { yeast water } \\
\text { soil extract }\end{array}$ & aspartic acid & $\begin{array}{c}\text { ammonium } \\
\text { sulfate }\end{array}$ \\
\hline & & g. & g. & agar & agar & agar \\
\hline \multirow[t]{3}{*}{ June 10.} & Oat & 0.48 & 1.07 & 150 & 300 & 60 \\
\hline & Pea & 0.61 & 1.36 & 1200 & 1200 & 400 \\
\hline & Vetch & 0.55 & 1.79 & 700 & 300 & 20 \\
\hline \multirow[t]{3}{*}{ July 20 . } & Oat & 3.00 & 4.40 & 10000 & 4000 & 7000 \\
\hline & Pea & 1.82 & 3.34 & 2000 & 6000 & 4000 \\
\hline & Vetch & 1.62 & 4.30 & 1000 & 400 & 1000 \\
\hline \multirow[t]{3}{*}{ August 30} & Oat & 0.68 & 1.06 & 1500 & 4000 & 2000 \\
\hline & Pea & 0.89 & 1.18 & 2500 & 8500 & 7000 \\
\hline & Vetch & 0.60 & 0.62 & 1500 & 2500 & 100 \\
\hline
\end{tabular}


Table 2. Increase upon incubation in the nitrogen content of solution cultures of rhizosphere microflora from oat, pea, and vetch plants. (Expressed as milligrams of nitrogen per culture flask).

\begin{tabular}{cccc}
\hline Period of incubation & Oat & Pea & Vetch \\
\hline June 10. - July 4. & 0.26 & 2.12 & 0.07 \\
July 20. - August 12. & 3.17 & 2.92 & 3.21 \\
August 30. - September 20. & 1.02 & 0.25 & 0.63 \\
\hline
\end{tabular}

Value required for significant difference at 5 per cent level 0.38 .

The results obtained on aspartic acid agar deserve most attention. The explanation of the large number of organisms from pea rhizosphere, found at the last sampling may lie in the fact that among the plants there were some fresh ones with an abundance of effective nodules. The nodules in the earlier samplings were nearly all colourless, and, hence, inactive (17). Thus this figure may be taken to agree with the speculations of WALLACE and LOCHHEAD, mentioned above. Even the number of colonies developed on the ammonia sulfate agar media from the pea roots flora of this sampling was great, in accordance with the finding of these investigators.

Earlier papers contain evidence that non-symbiotic nitrogen-fixing bacteria especially are stimulated in their development by legumes (9). STARKEy (14), however, reports that legumes had no more effect on the non-symbiotic nitrogenfixing organisms than did non-legumes. CLARK (2) points out in his review that at present neither adequate microbiological data nor acceptable crop yield data exist to warrant a positive statement to the effect that increased fixation of atmospheric nitrogen occurs in the rhizosphere of legumes or non-legumes.

The tests for nitrogen fixation in nitrogen-free mannitol solution media, performed with the same root material as the plate counts reported above, did not in general prove any superiority of the legumes over the non-legume (Table 2). Only in the first test the increase in the nitrogen content of the cultures inoculated with microflora from pea rhizosphere exceeds that of the other cultures. The nitrogen fixation may be attributed to the activity of anaerobic bacteria, since no sign of the occurence of Azotobacter was to be found, and according to other investigations, Clostridium species are known to be common in these soils. It is perhaps too much to imagine that the nitrogen fixation ability of the flora of the young pea plants could be attributed to the stronger utilization of oxygen by the roots, which would create conditions favourable for the anaerobic Clostridium population.

Undoubtedly, the importance of the rhizosphere microflora for the host-plant is considerable, but its effect on soil conditions may be less marked, due to the fact that the microscopic population stimulated by the plant roots loses its special quality soon after the death of the plants (14). In addition, the sphere of domination of the characteristic rhizosphere flora does not extend far from the root surface region (15). Therefore, as regards soil fertility, it is probably more necessary to investigate whether the various crops affect microbial activities in the soil as a whole. 
Table 3. Increase upon incubation in the nitrate-nitrogen content of soil samples from plots growing annual legume and non-legume crops (Expressed as $\mathrm{NO}_{3}-\mathrm{N}$ p.p.m. of soil dry matter). Experiment S I.

\begin{tabular}{|c|c|c|c|c|c|}
\hline \multirow{2}{*}{$\begin{array}{c}\text { Date of } \\
\text { samplings }\end{array}$} & \multicolumn{5}{|c|}{ Crop } \\
\hline & Oats & $\begin{array}{l}\text { Mixed pea } \\
\text { and oats }\end{array}$ & Pea & $\begin{array}{l}\text { Mixed vetch } \\
\text { and oats }\end{array}$ & Vetch \\
\hline \multicolumn{6}{|l|}{ In 1949} \\
\hline June 8 . & 17.3 & 12.9 & 23.1 & 26.7 & 29.3 \\
\hline August 1 & 23.2 & 19.8 & 34.9 & 24.6 & 29.7 \\
\hline September 13 . & 17.6 & 13.6 & 20.7 & 17.4 & 18.7 \\
\hline October 24 & 12.6 & 11.6 & 16.1 & 17.9 & 17.0 \\
\hline \multicolumn{6}{|l|}{ In 1950} \\
\hline June 6 . & 12.4 & 13.4 & 13.3 & 10.2 & 12.9 \\
\hline July 11. & 10.2 & 10.6 & 14.5 & 11.8 & 14.4 \\
\hline August 1. & 11.2 & 17.0 & 21.4 & 17.9 & 24.5 \\
\hline September 1 . & 4.5 & 4.5 & 10.9 & 8.7 & 10.6 \\
\hline October 6 & 6.1 & 7.6 & 10.1 & 6.6 & 10.4 \\
\hline
\end{tabular}

Value for significant difference at 5 per cent level 2.7 in 1949 , and 1.7. in 1950.

\section{Influence of legumes upon nitrification.}

Few methods exist at present for estimation of microbiological conditions in the soil. The two most commonly used indicators are the nitrification capacity of the soil and the production of carbon dioxide, either from the soil's own sources or from compounds added to it. These methods were used in this investigation also to indicate the influence of legumes on the microbial fertility of the soil.

First an examination of the nitrification of soil nitrogen was performed. The soil samples were bored from the middle between the plant rows, and pieces of roots or other undecomposed plant material were removed before weighing. Thus the results represent, at least in the main, the nitrification of soil nitrogen, including nitrogen of the excretions, provided such exist, and of the decomposed root matter.

The nitrification rate in soils growing annual legumes and nonlegumes shows (Table 3), in general, the marked superiority of the pea and vetch soils over the oats soil. The soils growing mixed crops show no difference from the oats soil, apart from a few cases when they may be even inferior to the oats soil. The data indicate a maximum in the rate of nitrification in August. This, however, may be due partly to the laboratory temperature, at its highest during the summer. Thus, only the differences between the data of the same sampling are reliable.

The residual effect of the annual plants on nitrification in the soil samples, that can be seen from Table 4, appears to be nearly similar in all plots. Some superiority in samples after pea may be found at the beginning of growing season, and the soil after vetch shows a maximum nitrification value in June. A decline in the nitrification of the soil after mixed or single vetch crop may be noted at the end of the season. 
Nitrification of soils taken from the ley experiments indicate a considerable difference between timothy and red clover soils in favour of the latter (Table 5). Even the mixed ley crop appears to be able to produce a higher nitrification rate than the single timothy crop, except at the beginning of the growing season. The superiority of the red clover and the mixed ley last no longer than until the middle of the following summer, as can be seen from the data on the residual effect of the leys reported in Table 6.

The higher nitrification rate under and some time after the legumes as compared to non-legumes noted in this investigation as well as in several earlier ones $(10,11)$ may be explained in various ways. The primary cause is probably connected with the amount of mobilizable organic nitrogen, which is greater in the legume plots (8), due either to the secretion of organic nitrogen compounds or to the lower carbon nitrogen ratio in the dying roots of the legumes. The accumulation of nitrate nitrogen in soil during incubation need not be associated with the abundance of nitrifying organisms, nor even with the natural nitrification capacity of the soil that depends on environmental conditions, such as aeration, acidity, and temperature. Even if ammonium nitrogen is added to the soil, the increase in nitratenitrogen over that of untreated soil probably depends more on the energy-nitrogen relationship in the soil than on the abundance of nitrifying organisms in that particular soil.

Nitrification of ammonium nitrogen in the soils of this investigation (Tables 7 and 8 ) provided no evidence of a stimulation of the nitrate formation in legume soils compared with non-legume soils. These tests were performed in the same way as the nitrification experiments described previously, but with an addition of 200 $\mathrm{mg}$ of ammonium nitrogen, in the form of ammonium sulfate, per $\mathrm{kg}$ of soil, and the nitrification of this was calculated as the difference between the nitrate-nitrogen content of these samples after incubation and of the samples incubated without any treatment. No lime was added in these tests to neutralize the acids formed by the nitrification of ammonium sulfate. Hence, the inferiority of clover soil to timothy soil may originate from the higher acidity of the former (8). In the soils from the annual crop plots, where the differences of the $\mathrm{pH}$-values are less distinct (8), no lower rate of nitrification of ammonium nitrogen could be detected in legume soils, except in the last test.

\section{Influence of legumes upon soil respiration.}

The influence of legumes upon soil respiration or carbon dioxide evolution from the soll was examined under the laboratory conditions only. An experiment was performed with soil samples, collected as usual from between the plant rows, and freed of every particle of macroscopic, undecomposed plant residue. The results obtained from this experiment were taken to show whether the various plants did exert any special effect upon the rate of carbon dioxide evolution from the soil organic matter, including the more humified plant residues. 
Table 4. Increase upon incubation in the nitrate-nitrogen content of soil samples from plots after annual legume and non-legume crops (Expressed as $\mathrm{NO}_{3}-\mathrm{N}$ p.p.m. of soil dry matter). Experiment S II.

\begin{tabular}{lccccc}
\hline \multirow{2}{*}{$\begin{array}{c}\text { Date of } \\
\text { samplings }\end{array}$} & Oats & $\begin{array}{c}\text { Mixed pea } \\
\text { and oats }\end{array}$ & Pea & $\begin{array}{c}\text { Mixed vetch } \\
\text { and oats }\end{array}$ & Vetch \\
\cline { 2 - 6 } May 9. & 12.1 & 12.8 & 15.0 & 13.0 & 13.5 \\
June 8. & 11.3 & 12.0 & 12.2 & 13.6 & 16.0 \\
July 13. & 18.8 & 17.4 & 15.6 & 18.6 & 17.4 \\
August 9. & 15.5 & 13.2 & 17.7 & 17.3 & 15.8 \\
September 19. & 11.7 & 10.2 & 11.6 & 9.1 & 6.8 \\
\hline
\end{tabular}

Value required for significant difference at 5 per cent level 1.6.

Table 5. Increase upon incubation in the nitrate-nitrogen content of soil samples from the ley plots. (Expressed as $\mathrm{NO}_{3}-\mathrm{N}$ p.p.m. of soil dry matter.) Experiment $\mathrm{N} \mathrm{I}$.

\begin{tabular}{lccc}
\hline $\begin{array}{c}\text { Date of } \\
\text { samplings }\end{array}$ & Timothy & Ley crop & Red clover \\
\cline { 2 - 4 } May 12. & 16.1 & 15.7 & 23.4 \\
June 13. & 6.5 & 9.2 & 12.7 \\
July 14. & 7.0 & 9.3 & 12.4 \\
August 8. & 8.1 & 9.7 & 13.8 \\
September 12. & 7.1 & 14.7 & 22.0 \\
October 6. & 6.2 & 10.2 & 16.0 \\
\hline
\end{tabular}

Value required for significant difference at 5 per cent level 1.6.

Table 6. Increase upon incubation in the nitrate-nitrogen content of soil samples from the plots after the leys. (Expressed as $\mathrm{NO}_{3}-\mathrm{N}$ p.p.m. of soil dry matter.) Experiment N II.

\begin{tabular}{lccc}
\hline $\begin{array}{c}\text { Date of } \\
\text { samplings }\end{array}$ & Timothy & Preceding ley crop & Red clover \\
\cline { 2 - 4 } October 27. in 1949 & 8.9 & Mixed crop & 15.7 \\
May 13. in 1950 & 10.2 & 13.2 & 13.5 \\
June 12. & 12.4 & 15.5 & 17.4 \\
July 15. & 16.7 & 14.9 & 21.9 \\
August 2. & 21.4 & 22.9 & 11.6 \\
September 12. & 9.4 & 11.3 & 21.9 \\
\hline
\end{tabular}

Value required for significant difference at 5 per cent level 1.7.

Table 7. Nitrification of ammonium sulfate added to samples of soil growing annual legume and nonlegume crops. (Expressed as nitrate- nitrogen formed, p.p.m. of soil dry matter). Experiment S I.

\begin{tabular}{ccccccc}
\hline $\begin{array}{c}\text { Date of } \\
\text { samplings }\end{array}$ & Mats & $\begin{array}{c}\text { Crop } \\
\text { and oats }\end{array}$ & Pea & $\begin{array}{c}\text { Mixed vetch } \\
\text { and oats }\end{array}$ & Vetch \\
\hline June 5. & 157 & 153 & 147 & 152 & 175 & 118 \\
July 11. & 122 & 130 & 122 & 125 & 163 \\
August 1. & 171 & 165 & 144 & 156 & 163 \\
\hline
\end{tabular}

Value required for significant difference at 5 per cent level 13 
Table 8. Nitrification of ammonium sulfate added to samples of the soil growing ley crops. (Expressed as nitrate-nitrogen formed, p.p.m. of soil dry matter). Experiment N I.

\begin{tabular}{cccc}
\hline Date of & \multicolumn{2}{c}{ Ley crop } \\
samplings & Timothy & Mixed crop & Red clover \\
\hline June 13. & 92 & 89 & 83 \\
July 14. & 95 & 87 & 68 \\
August 8. & 105 & 101 & 93 \\
\hline
\end{tabular}

Value required for significant difference at 5 per cent level 6.

Table 9. Carbon dioxide evolved from the soil samples obtained from the plots of annual legume and non-legume crops. (Expressed as milligrams of $\mathrm{CO}_{2}$ per 100 grams of fresh soil).

\begin{tabular}{lrrrrr}
\hline \multirow{2}{*}{$\begin{array}{c}\text { Period of } \\
\text { incubation }\end{array}$} & Oats & $\begin{array}{c}\text { Mixed pea } \\
\text { and oats }\end{array}$ & Pea & $\begin{array}{c}\text { Mixed vetch } \\
\text { and oats }\end{array}$ & Vetch \\
\cline { 2 - 6 } & 11 & 7 & 13 & 9 & 16 \\
September 25. - October 3. & 7 & 3 & 4 & 5 & 4 \\
October 3. - 9. & 10 & 9 & 10 & 9 & 10 \\
October 9. - 16. & 15 & 13 & 13 & 14 & 16 \\
October 16. - 23. & 13 & 14 & 13 & 17 & 14 \\
October 23. - November 13. & 56 & 46 & 53 & 54 & 60
\end{tabular}

Table 10. Carbon dioxide evolved from the soil samples obtained from the plots of ley crops. (Expressed as milligrams of $\mathrm{CO}_{2}$ per 100 grams of fresh soil).

\begin{tabular}{lccc}
\hline Period of incubation & \multicolumn{3}{c}{ Ley crop } \\
\cline { 2 - 4 } & Timothy & Mixed crop & Red clover \\
\hline September $25 .-$ October 3. & 29 & 28 & 28 \\
October $3 .-9$. & 14 & 14 & 12 \\
October $9 .-16$. & 11 & 11 & 9 \\
October $16 .-23$. & 27 & 24 & 27 \\
October $23-$ November 13. & 23 & 23 & 20 \\
\hline September $25 .-$ November 13. & 104 & 100 & 96
\end{tabular}

The results, reported in Tables 9 and 10 , show no superiority of legumes in stimulating the evolution of carbon dioxide from the soil organic matter. Rather a contrary tendency is noted, particularly with red clover. The higher soil respiration rate found under and after legumes $(7,13)$ must therefore be attributed to the more rapid decomposition of the legume residues. Some experiments concerning the carbon dioxide production from oats, pea and vetch residues, and from the residues of red clover and timothy, all containing both stubble and roots, confirmed this opinion. 


\section{Summary.}

An attempt has been made in the present investigation to elucidate the influence of growing legumes upon the microbial population and upon its activities in the soil. Annual legumes, pea and vetch were compared with oats, and red clover with timothy.

At the beginning and at the end of the summer the number of bacteria, calculated through various culture media, appeared to be greater in the rhizosphere of the pea plants than under the vetch or oat plants. The rhizosphere flora of the young pea plants showed a capacity for more active nitrogen fixation than that of the young vetch or oat plants, but later the superiority of the pea plants disappeared.

A higher rate of nitrification under and for some time after the legume crops compared with the corresponding non-legume crops was noted. Nitrification of added ammonium sulfate did not occur more actively under the legumes, due either to the lack of a stimulation of the nitrifying flora, or to the higher acidity in the legume soils. Compared with the non-legumes, the legumes could not be found to stimulate carbon dioxide production from the soil in any other way than through their more easily decomposable residues.

Within the bounds of this investigation no special effect of legumes upon the soil flora could be established that cannot be explained on the basis of their nitrogen economy, either their utilizing soil nitrogen to a smaller degree than non-legumes, or due to composition of their roots and stubble. Under the field conditions, however, several other factors not demonstrable from this material inay exist.

\section{REFERENCES.}

(1) Berge, T. O. 1941. Determination of nitrate-nitrogen with a photoelectric colorimeter. Soil Sci. 52 , p. $185-191$.

(2) Clark, F. E. 1949. Soil microorganisms and plant roots. Advances in Agronomy, Vol. I, p. 242 - 288.

(3) Cramér, H. 1949. Sannolikhetskalkylen och några av dess användningar. Uppsala, 255 p.

(4) Creuzberg, U. 1928. Untersuchungen über den Einfluss des Pflanzenbestandes auf das Bakterienleben im Boden. Landw. Jahrb., 68, p. 75-115.

(5) Eggleton, W. G. E. 1938. The influence of environmental factors on numbers of soil microorganisms. Soil Sci., 46, p. $351-363$.

(6) GRÄF, G. 1930. Über den Einfluss des Pflanzenwachstums auf die Bakterien im Wurzelbereich. Centrbl. Bakt. (II), 82, p. $44-69$.

(7) Headden, W. P. 1927, 1930. Effects of clover and alfalfa in rotation. Col. Exp. Sta. Bul. 319 , $362-364$.

(8) Karla, A. Influence of legumes upon soil fertility. Ann. Acad. Sci. Fennicae (In the press).

(9) Löhnis, F. 1926. Effect of growing legumes upon succeeding crops. Soil Sci,. 22, p. 355-389.

(10) Lyon, T. L., Bizzell, J. A. and Wilson, B. D. 1920. The formation of nitrates in a soil following the growth of red clover and of timothy. Soil Sci., 9, p. 53-64. 
(11) Newton, J. D., Wyatt, F. A., Ignatieff, V., and Ward, A. S. 1939, Nitrification under and after alfalfa, brome, timothy and Western rye grass. II. Soil microbiological activity. Canad. Journ. Res. 17 C, p. $256-293$.

(12) Rider, P. 1948. An introduction to modern statistical methods. 4th print. New York, 220 p.

(13) Ripley, P. O. 1941. The influence of crops upon those which follow. Sci. Agr., 21, p. 522 - 583

(14) Starkey, R. L. 1929. Some influence of the development of higher plants upon the microorganisms in the soil: II. Influence of the stage of plant growth upon abundance of organisms. Soil Sci., 27 , p. $355-378$

(15) —- 1931. Some influence of the development of higher plants upon the microogranisms in the soil: IV. Influence of proximity to roots on abundance and activity of microorganisms. Soil. Sci., 32 , p. $367-393$.

(16) Trmonin, M. I. 1940. The interaction of higher plants and soil microorganisms. I. Microbial population of rhizosphere of seedling of certain cultivated plants. Canad. Jour. Res., $18 \mathrm{C}, \mathrm{p}$. $307-317$.

(17) Virtanen, A. I., Jorma, J., Linkola, H., and Linnasalmi, A. 1947. On the relation between nitrogen fixation and leghaemoglobin content of leguminous root nodules. Acta Chem. Scandinavica, 1, p. $90-111$.

(18) Wallace, R. H. and Lochhead, A. G. 1949. Qualitative studies of soil microorganisms: VIII. Influence of various crop plants on the nutritional groups of soil bacteria. Soil Sci., 67, p. $63-69$.

(19) - $\longrightarrow$ - 1950. Qualitative studies of soil microorganisms IX. Amino acid requirements of rhizosphere bacteria. Canad. Jour. Res., 28 C, p. 1-6.

S E L O S T U.

\section{PALKOKASVIEN VAIKUTUKSESTA MAAN MIKROBITOIMINTAAN}

ArMi KaILA

Helsingin yliopiston maanviljelyskemian laitos.

Viime aikoina on entistä enemmän kiinnitetty huomiota korkeampien kasvien ja maan mikroorganismien väliseen vuorovaikutukseen ja väitetty jopa, että korkeammat kasvit säännöstelevät maan mikrobistoa voimakkaammin kuin muut ympäristötekijät (5). Palkokasvien maan kasvukuntoa parantavan vaikutuksenkin katsotaan johtuvan osittain siitä, että useat hyödylliset mikro-organismit viihtyvät niiden juuristossa $(9)$.

Edellä olevassa tutkimuksessa on vertailtu palkokasvien ja heinäkasvien vaikutusta maan mikrobien määrään ja toimintaan, toisaalta hernettä ja virnaa kauraan, toisaalta puna-apilaa timoteihin. Myös sekakasvustot olivat tutkimuksen kohteena. Näytteet oli kerätty kenttäkokeista, mutta varsinaiset tutkimukset suoritettiin laboratorion olosuhteissa. Tutkimuksessa päädyttiin seuraaviin tuloksiin.

Kesän alussa ja lopussa oli herneen juuriston maauute-hiivauute-, asparagiinihappo- ja ammoniumsulfaattiagarilla kasvavien bakteerien lukumäärä suurempi kuin kauran, keskikesällä ei ollut havaittavissa herneen paremmuutta tässä suhteessa. Virnan juuriston organismit kasvoivat verraten heikosti kaikilla näillä elatusaineilla. Asparagiinihappoagarilla kasvavien bakteerien suuri lukumäärä kesän lopussa kerätyissä herneen juuristoissa voi kytkeytyä punaisten juurinystyröiden runsaaseen esiintymiseen vielä vihreisssä herneyksilöissä, joita oli joukossa. Aerobeja vapaita typensitojia ei kasvanut typettö- 
mällä mannitoliagarilla mistään näytteistä, mutta typen sidontaa oli todettavissa mannitoliravintoliuoksessa herneen organismeilla kesän alussa, kaikilla kasveilla keskikesällä, kauralla sekä hiukan myös virnalla kesän lopussa. Typen sitojina toimivat ilmeisesti Clostridium-lajit.

Maan typen nitrifioituminen oli selvästi tehokkaampaa palkokasviruuduilla, jopa nurmikasviseoksissakin, kuin puhtaissa kaura- tai timoteikasvustoissa. Palkokasvien jälkivaikutus tuntui vain seuraavan kasvukauden alussa. Palkokasvien paremmuus perustunee helposti mobilisoituvan typellisen aineksen kertymiseen, koska ei voitu todeta lisätyn ammoniumsulfaatin tehokkaampaa nitrifioitumista palkokasviruuduilta otetuissa näytteissä vastaaviin kaura- ja timoteiruutujen näytteisiin verrattuna.

Palkokasvien ei todettu tehostavan hiilidioksidin kehittymistä maanäytteistä, joten eräitten tutkijoiden $(7,13)$ tähdentämä maan hengityksen lisääntyminen palkokasvien vaikutuksesta johtunee lähinnä niiden helposti hajaantuvista kasvinjätteistä tai juurten hengityksestä.

Tutkimuksen tulosten perusteella ei voitu todeta palkokasveilla olevan mitään sellaista erikoisvaikutusta maan mikrobitoimintaan, joka ei johtuisi välillisesti tai välittömästi niiden omavaraisesta typpitaloudesta. On mahdollista, että kenttäolosuhteissa on vaikuttamassa muita tekijöitä, joita ei voitu todeta tämän aineiston perusteella. 